J. P. Tilt, who took part in the investigation. Mr. E. F. Fincham kindly helped in connexion with the refraction test. The continued financial support of the Medical Research Council is gratefully acknowledged.

$$
\begin{gathered}
\text { Chelsea Polytechnic, } \\
\text { London, S.W.3. } \\
\text { April } 7 .
\end{gathered}
$$

${ }^{1}$ Jord, M. P,, Brit. J. Ophthal., 35, 21 (1951).

${ }^{2}$ Lord, M. P., Nature $[169,1011$ (1952)].

${ }^{3}$ Lord, M. P., and Wright, W. D., Nature, 162, 25 (1948).

- Duke-Elder, W. S., "Text Book of Ophthalmology", 1, 602 (1932).

\section{Education of the Deaf}

MAY I be allowed to make a material correction to the otherwise admirable account in Nature of September 27, p. 525, of the discussion on the "Education of the Deaf" at the recent meeting of the British Association? My own paper was specifically limited to the problem of educating the young, totally deaf--whether born deaf, or those who become totally deaf before learning to speak.

It is common ground that such children constitute a very difficult problem. Mr. Greenaway reported that of twenty deaf pupils leaving his school this year, 60 per cent could be considered as successes, but the remaining 40 per cent were unsuccessful. For these he suggested that something more than pure oral teaching should be added.

Mr. Askew, of the Mary Hare Grammar School, pointed out that the born-deaf pupils entering his school at $13+$ years were 2-3 years retarded in vocabulary. Prof. and Mrs. Ewing claim that with skilful home training from a very early age, deaf children of two had been trained to lip-read. But they have also admitted that all totally deaf children are not equally teachable.

My purpose was to plead for the experimental use of a systematic sign language, in which every sign should be the equivalent of a spoken word, and that suitable parents or nurses should be trained to use the new signs, and to talk to the young deaf children, in signs, just as a hearing mother talks to her young hearing children in words. In this experiment no effort should be required on either side. At first the deaf child would understand nothing : then gradually the meaning of the various signs would begin to dawn on them.

Mr. Greenaway had made the interesting suggestion that parents or nurses using the new sign language should speak as they signed. In this way the deaf children would get to realize that the mouth-gestures of speech and the pantomimic hand-gestures of the new sign language meant the same things. It seems not unlikely that at the age of four, totally deaf children might acquire a vocabulary of as many signs as a hearing child of equal intelligence would know words. A born deaf child of four with a vocabulary approaching 2,000 'words' would obviously be immensely more teachable than even the best of the pure oral successes. It is also obvious that signs which are completely visible should be much easier for the deaf child to imitate than spoken words are to the hearing child; for the method of manufacture of speech-sounds is largely a secret process.

I have made no 'recommendations' - I plead for the carrying out of an experiment which seems to offer valuable knowledge and material help to the young born deaf. I plead in good company, for when Lady Paget and I met Dr. Helen Keller in Cape Town last year, she was greatly interested in the new signs, and, after copying some of them for herself, she gave me this message: "Let the experiment be tried".

11 Cottesmore Gardens,
Kensington,
London, W.8.

R. A. S. PAGE'T

Oct. 1 .

\section{In vitro Cultures of a Fern Callus}

$I_{N}$ recent years, several reports of the successful growth in sterile culture of callus tissues derived from various pteridophytes have appeared ${ }^{1}$. A callus culture possessing several unusual morphological, cytological and metabolic features has been obtained from gametophytes of Pteridium aquilinum (L.) Kuhn, var. latiusculum (Desv.) Underw. ${ }^{2}$, which had been growing in sterile culture on an agar medium containing Knudson's solution of inorganic salts ${ }^{3}$, Berthelot's trace element solution ${ }^{4}, 2$ per cent glucose and $0.5 \mathrm{gm} . / 1$. yeast extract (autoclaved) at Harvard University, United States. Soon after these gametophyte cultures were brought to Manchester, England (in September 1950), a callus-like growth was observed in one of the tubes. When subcultured on to the same medium, with Knop's inorganic salt solution $^{4}$ substituted for Knudson's, the abnormal tissue continued to grow in a disorganized manner. It has now been through sixteen passages, each of four to six weeks duration, and in each passage there has been a six-to ten-fold increase in the size of the inoculum.

The cultures are deep green in colour and form coherent but friable masses. They are predominantly filamentous, with numerous branched filaments radiating from centres of growth. Continued divisions in various planes result in the formation of regions of highly vacuolated, large-celled parenchymatous tissue in some of the older parts of the cultures. Whitish or pale-green outgrowths project from the surfaces of many of the cultures. These are compact tissues composed of small, deeply staining parenchyma cells. Meristematic growth in the outgrowths is confined to certain localized superficial regions behind which is often a core of elongated cells. Some of these cells may be further differentiated as short scalariform or reticulate tracheids. A variety of treatments has as yet failed to promote further regenerative growth of these bud-like structures.

During the first two passages prothallial regeneration occurred on five occasions, but has not occurred since, either spontaneously or following experimental treatment. The strain of gametophytes from which the callus arose was haploid ${ }^{5}, n=52$. When first examined in the fourth passage, cells of the callus had approximately 100 chromosomes; but on subsequent examination of material in the twelfth and fourteenth passages chromosome numbers were found to vary irregularly between 150 and 200. The callus is now irregularly aneuploid.

Nutritional requirements of the callus are very simple. Slow but continued growth is possible on an agar medium containing inorganic salts only. Rapid growth occurs when inocula are totally submerged in a liquid medium containing only inorganic salts and 3 per cent glucose. 